\title{
SCHOLARLY EVENTS
}

\section{PICTURING EMPIRES: \\ PHOTOGRAPHY AND SOCIAL CHANGES \\ IN 19th CENTURY MULTIETHNIC ENVIRONMENT}

\section{E. A. Vishlenkova}

The A. Poletaev Institute

for Theoretical and

Historical Studies

in the Humanities (IGITI),

National Research University

"Higher School of Economics"

(Moscow)
Е. А. Вишленкова

Институт гуманитарных и историко-теоретических исследований

им. А. Полетаева (ИГИТИ),

Национальный исследовательский

университет «Высшая школа экономики" (Москва)

E-mail: evishlenkova[at]mail.ru

Copyright: (C) 2014 Vishlenkova. This is an open-access publication distributed under the terms of the Creative Commons Attribution License (CC BY 4.0), which permits unrestricted use, distribution, and reproduction in any medium, provided the original author and source are credited.

\section{ИЗОБРАЖАЯ ИМПЕРИИ: \\ ФОТОГРАФИЯ И СОЦИАМЫНЫЕ ИЗМЕНЕНИЯ В ПОИИЭТНИЧЕСКОМ КОНТЕКСТЕ XIX ВEKA}

The international conference "Picturing Empires: Photography and Social Change in 19th Century Multiethnic Environments" was held in Basel (Switzerland) on August 27 to 29, 2014. Scholars interested in the histories of Russia, South Africa, America, Central Asia, Great Britain, France, and the Baltic States took part in the conference-this provided a comparative approach to the theme. Specialists in social history, art theory and history, cultural topography, and the history of medicine, science and 
technology participated in the event. The conference took place at the Augusta Raurica Country Castle.

Dr. Benjamin Schenk, the conference organizer, is well-known in the academic world for his works in the sphere of historical memory, mental geography, and the social history of Russia. His broad international network made possible the representation of scholars from different countries, national research traditions, and scientific disciplines. The conference represents one part of a larger collective project on the role of technological and technical innovation in the social modernization of the Russian Empire.

Five panels met for three days in the chateau: 1) Visual Representations Before and After the Invention of Photography (presenters Elena Vishlenkova, Heather Sonntag, James Ryan, and commentator Mark Bassin); 2) Picturing Imperial Subjects in the Age of Photography (presenters Lorenna Rizzo and Olga Annanurova, and commentator Andreas Broeckmann); 3) Visualizing Multiethnicity (presenters Laura Ellias, Baiba Tetere, and Martina Baleva, and commentator Elizabeth Edwards); 4) Visualizing Religious Diversity (presenters Eugene Avrutin, Jannifer Keating, Jurg Schneider, and Arno Schubbach, and commentator Arno Schubbach); and 5) Industrial Photography (presenters Lanka Fehrenbach, Celina Assegond, Noeme Santana, and Monika Dommann, and commentator Monika Dommann). The conference format required preliminary preparation of reports, perusal of online manuscripts by the participants of the conference, visual presentations and explanations of methods used in image analysis, specially invited commentators' speeches on reports, and detailed discussion among all participants. Further, participants formulated questions relevant to the history of photography and worked to extract theoretical conclusions from presented cases. As a result, the conference theme was not just a simple "umbrella" term to describe different and poorly connected cases.

The conference generated a list of questions regarding the use of images in scholarly studies: How do we look at images? How are we allowed to look at them and to see them? How do new technologies and the development of technique influence how we perceive images? What role do customers' and producers' interests play in the looking policy? How important is cultural and local context in correctly interpreting images? Fierce debates occurred over such questions as: can we reconstruct gaze and contemporaries' perception? Would this reconstruction entail the reproduction of new interpretations and their incorporation into new discourses? This anxiety is a natural consequence of adopting a postcolonial and feminist critique. Obvious deconstruction of the research hypothesis has occurred in recent years due to the development of new science and technology history. Could the object of the picture influence its own image? How could it be made? In other words, the limits and means of the construction of subjectivity and objectivity excited explorers of the 
visual. Each panel addressed additional questions: How do photographers take part in national conventions? What do they bring to these conventions? How are photos collected and preserved for historians and other specialists in archives, museums, and private collections? Participants offered potential answers to the question of photos' power to witness, help, remember, construct, change, and popularize.

It should be noted that each presenter discussed photograph series and albums, rather than single images. This suggests that the single image is not a visual narrative. It offers a unique, but separate testimony, a unit of the visual language. The conference title problematizes the role of the photographer in representations of country, groups, and community (i.e. the metropole's success in the "civilizing of natives"), the empire's selfconfidence in an international context, and the mapping of geographic and mental spaces. The photographer helps to structure the social world (as multiethnic, socially heterogenous) and to create national identities. However, as the discussed cases revealed, the photographer is also a channel for overcoming isolation and local limitation. Industrial photography provides people with a sense of a global community by depicting global problems (i.e. air pollution made by factories).

Participants discussed the multiplicity of imperial modernities and their reception by contemporaries. They also paid particular attention to the material component of visual images: the paper, chemicals, and optical equipment. As long as pictures are a means of social communication, its creators, consumers, and investigators are in need of its signatures. It issues a challenge to the correlation between visual and verbal languages, and raises questions about the place of photography among other media (graphics, caricatures, maps, and films).

The conference demonstrates how one group of investigators have used Foucault's theoretical framework in their research and how another group has challenged Foucault's rigorous arrangement of discourse and power. At the same time, no one argued for a universal methodological framework. Rather they agreed with Dr. Benjamin Shenk's arguments in favor of collective elaboration of theory in scholarship on the history of photography, support for an interpretational openness in approaching images, and the importance of analyzing gaps in our comprehension. 